Energy Research Journal 1 (1): 32-35, 2010

ISSN 1949-0151

(C) 2010 Science Publications

\title{
Estimating the Energy Indices and Profitability of Strawberry Production in Kamyaran Zone of Iran
}

\author{
Payman Salami, Hojat Ahmadi and Alireza Keyhani \\ Department of Agricultural Machinery Engineering, \\ Faculty of Agricultural Engineering and Technology, University of Tehran, \\ P.O. Box 4111, Karaj 31587-77871, Iran
}

\begin{abstract}
Problem statement: The aim of this research is to determine the energy indices and to make a cost analysis of strawberry grown in open field in Kamyaran zone of Iran. Approach: The data used in the study were obtained from 35 local strawberry growers by using a face-to-face questionnaire in August-September 2009. Results: Total energy input for strawberry production was calculated to be $36822.9 \mathrm{MJ}^{-\mathrm{ha}^{-1}}$. The Energy ratio was 0.48 and energy productivity was found to be $0.25 \mathrm{~kg} \cdot \mathrm{MJ}^{-1}$. About $74.5 \%$ of the total energy inputs used in strawberry production was nonrenewable while only about $25.5 \%$ was renewable. The share of $56.6 \%$ of the total energy input was depended on the indirect form, whereas $43.4 \%$ of the total energy input was in the direct form. Specific energy was $3.96 \mathrm{MJ} \cdot \mathrm{kg}^{-1}$. Economic analyses showed that profit/cost ratio and net profit were 1.49 and $4616.9 \$ \cdot \mathrm{ha}^{-1}$, respectively. Conclusion: The net energy in the study area was negative. This means that the amount of output energy is less than input energy and production in this situation is irrational, thus efficient use of resources and proper land management is needed.
\end{abstract}

Key words: Economic analysis, energy efficiency, energy productivity, net energy, specific energy

\section{INTRODUCTION}

Strawberry is an herbaceous perennial plant having a compressed, shortened stem and produces stolons. The fruit is an Achene attached to a juicy, enlarged receptacle. It is one of the most popular fruits in the world and per capita consumption is increasing annually. Strawberry is the most popular yogurt flavor in many countries. Fruits are eaten raw or used in making juice, desserts, jam, syrup and wine (Biswas et al., 2007).

Strawberries are from the Rosaceae family. The name strawberry has a couple of derivations. One was thought to come from the fact that the berries on runners are "strewn" about on the plants and "strewn berry" eventually became "Strawberry". Another was that they were planted in straw mulch to keep them clean and hence straw berries (Kirkpatrick, 2008).

The strawberry is among the first of the fresh fruits and very attractive on the market. A rapid cash return is predicted to strawberry growers. Experience of investigators and local growers is the best guide in selecting profitable culture measures (Kikas and Luik, 2009).
The relation between agriculture and energy is very close. Agriculture itself is an energy user and energy supplier in the form of bio-energy. At present productivity and profitability of agriculture depend on energy consumption. For the growth and development, energy demand in agriculture can be divided into direct and indirect, renewable and non-renewable energy. Energy inputs are sun and support energy. Support direct energy is required for land preparation, irrigation, harvest, post harvest processing, transportation of agricultural inputs and outputs. Support indirect energy is used in the form of fertilizer and pesticides. Energy use depends on mechanization level, the quantity of active agricultural worker and cultivable land (Salami et al., 2010).

In developing countries like Iran, agricultural growth is essential for fostering the economic development and meeting the ever-higher demands of the growing population. Energy in agriculture is important in terms of crop production and agro processing for value adding (Salami et al., 2009).

Energy productivity is an important index for more efficient use of energy although higher energy productivity does not mean in general, more economic

Corresponding Author: Payman Salami, Department of Agricultural Machinery Engineering, Faculty of Agricultural Engineering and Technology, University of Tehran, P.O. Box 4111, Karaj 31587-77871, Iran Tel: +989183734751 Fax: +98 2166593099 
Energy Rec. J. 1 (1): 32-35, 2010

feasibility. However, the energy analysis shows the methods to minimize the energy inputs and therefore to increase the energy productivity (Fluck and Baird, 1982).

\section{MATERIALS AND METHODS}

The data were collected from 35 farmers growing strawberry in Kamyaran zone by using a face-to-face questionnaire in August-September 2009. This zone is located in Kurdistan province of Iran.

As it is shown in Eq. 1, the sample size was determined by using the simple random sampling method (Salami et al., 2009):

$$
\mathrm{n}=\frac{\mathrm{N} \times \mathrm{s}^{2} \times \mathrm{t}^{2}}{(\mathrm{~N}-1) \mathrm{d}^{2}+\mathrm{s}^{2} \times \mathrm{t}^{2}}
$$

In which:

$\mathrm{n}=$ The required sample size

$\mathrm{s}=$ The standard deviation

$\mathrm{t}=$ The $\mathrm{t}$ value at $95 \%$ confidence limit (1.96)

$\mathrm{N}=$ The number of holding in target population

$\mathrm{d}=$ The acceptable error (permissible error 10\%)

The energy efficiency of the agricultural system has been evaluated by the energy ratio between output and input. Human labor, machinery, diesel fuel, fertilizer and Ecesis amounts and output yield values of strawberry crops have been used to estimate the energy ratio. The amounts of input were calculated per hectare and then, these input data were multiplied with the coefficient of energy equivalent. Energy equivalents shown in Table 1 were used for estimation.

Basic information on energy inputs and strawberry yields were entered into Excel and SPSS 17 spreadsheets. Based on the energy equivalents of the inputs and output (Table 1), the energy ratio (energy use efficiency), energy productivity, specific energy and net energy were calculated, as they are shown in Eq. 2-5 (Mandal et al., 2002; Mohammadi and Omid, 2010; Singh et al., 1997):

Energy ratio $=\frac{\text { Energy output }\left(\mathrm{MJ} \cdot \mathrm{ha}^{-1}\right)}{\text { Energy input }\left(\mathrm{MJ} \cdot \mathrm{ha}^{-1}\right)}$

Energy productivity $=\frac{\text { Strawberry output }\left(\mathrm{kg} \cdot \mathrm{ha}^{-1}\right)}{\text { Energy input }\left(\mathrm{MJ} \cdot \mathrm{ha}^{-1}\right)}$

Specific energy $=\frac{\text { Energy input }\left(\mathrm{MJ} \cdot \mathrm{ha}^{-1}\right)}{\text { Strawberry output }\left(\mathrm{kg} \cdot \mathrm{ha}^{-1}\right)}$

Net energy $=$ Energy output $\left(\mathrm{MJ} \cdot \mathrm{ha}^{-1}\right)$

$$
\text { -Energy input (MJ.ha } \left.{ }^{-1}\right)
$$

Table 1: Energy equivalent of inputs and output in strawberry

\begin{tabular}{|c|c|c|c|}
\hline Particulars & Unit & $\begin{array}{l}\text { Energy equivalent } \\
\text { (MJ.unit }^{-1} \text { ) }\end{array}$ & Reference \\
\hline \multirow{2}{*}{$\begin{array}{l}\text { A. Inputs } \\
\text { 1. Human labor }\end{array}$} & & & \\
\hline & $\mathrm{h}$ & 1.96 & $\begin{array}{l}\text { (Erdal et al., 2007; } \\
\text { Singh and Mittal, 1992) }\end{array}$ \\
\hline 2. Machinery & $\mathrm{kg}$ & & \\
\hline Tractor & $\mathrm{kg}$ & 138.00 & (Kitani, 1999) \\
\hline Plow & $\mathrm{kg}$ & 180.00 & (Kitani, 1999) \\
\hline Disk harrow & $\mathrm{kg}$ & 149.00 & (Kitani, 1999) \\
\hline 3. Diesel fuel & $\mathrm{L}$ & 56.31 & $\begin{array}{l}\text { (Erdal } \text { et al., 2007; } \\
\text { Singh and Mittal, 1992) }\end{array}$ \\
\hline \multicolumn{3}{|l|}{ 4. Fertilizers } & (Kitan \\
\hline (P) & $\mathrm{kg}$ & 3.50 & (Salami et al., 2010) \\
\hline 5. Manure & $\mathrm{kg}$ & 0.30 & (Singh and Mittal, 1992) \\
\hline 6. Ecesis & $\mathrm{kg}$ & 0.80 & (Singh and Mittal, 1992) \\
\hline B. Outputs (Yield) & $\mathrm{kg}$ & 1.90 & (Singh and Mittal, 1992) \\
\hline
\end{tabular}
production

Indirect energy included energy embodied in ecesis, fertilizers, manure and machinery while direct energy covered human labor and diesel used in the strawberry production. Non-renewable energy includes diesel, fertilizers and machinery and renewable energy consists of human labor, ecesis and manure. In the last part of the study, economic analysis of strawberry production was investigated and net profit and benefitcost ratio was calculated. The net return was calculated by subtracting the total cost of production from the gross value of production per hectare. The benefit-cost ratio was calculated by dividing the gross value of production by the total cost of production per hectare (Demircan et al., 2006; Ozkan et al., 2004).

\section{RESULTS AND DISCUSSION}

Analysis of input-output energy use in strawberry production: Table 2 shows the amounts of used inputs in the strawberry production, energy equivalences, ratio of inputs and output, energy productivity, specific energy and net energy. The last column in Table 2 gives the percentage of each input of the total energy input.

The most of the agricultural operations was done manually in the study area, while using the agricultural machinery was limited to some areas and only for land preparation. According to the estimation of data in Table 2, the average human labor required in the study area was $1231.4 \mathrm{~h} \cdot \mathrm{ha}^{-1}$ and machine power was just $2.2 \mathrm{~h}^{\mathrm{ha}} \mathrm{a}^{-1}$.

Total energy consumed in various farm operations during strawberry production was $36822.9 \mathrm{MJ}^{\mathrm{ha}}{ }^{-1}$. Irrigation energy consumed $34.3 \%$ of total energy followed by nitrogen fertilizer $31.6 \%$ during production period. Total energy output was $17680.3{\mathrm{MJ} . h a^{-1} \text { and }}^{-1}$ the average annual yield of strawberry farms was $9305.4 \mathrm{~kg} \cdot \mathrm{ha}^{-1}$. It is shown in Table 2 that machinery was the least demanding energy input for strawberry production with $130.5 \mathrm{MJ}^{-h^{-1}}$ (only $0.4 \%$ of the total energy input), followed by diesel fuel (for land

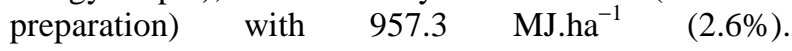


Energy Rec. J. 1 (1): 32-35, 2010

Table 2: Amounts of inputs and output in strawberry production

\begin{tabular}{|c|c|c|c|}
\hline Inputs and output & Quantity per unit area (ha) & Total energy equivalent $\left(\mathrm{MJ} \mathrm{ha}^{-1}\right)$ & Percent \\
\hline \multicolumn{4}{|l|}{ A. Inputs } \\
\hline 1. Human labor (h) & 1231.4 & 2413.6 & 6.6 \\
\hline 2. Machinery (h) & 2.2 & 130.5 & 0.4 \\
\hline 3. Diesel fuel (L) & 17.0 & 957.3 & 2.6 \\
\hline \multicolumn{4}{|l|}{ 4. Chemical fertilizers $(\mathrm{kg})$} \\
\hline Nitrogen $(\mathrm{N})$ & 324.3 & 11650.8 & 31.6 \\
\hline Phosphate (P) & 592.7 & 2074.5 & 5.6 \\
\hline 5. Manure $(\mathrm{kg})$ & 19037.6 & 5711.3 & 15.5 \\
\hline 6. Ecesis $(\mathrm{kg})$ & 1582.1 & 1265.7 & 3.4 \\
\hline 7. Irrigation $\left(\mathrm{m}^{3}\right)$ & 31428.6 & 12619.2 & 34.3 \\
\hline Total energy input (MJ) & - & 36822.9 & 100.0 \\
\hline \multicolumn{4}{|l|}{ B. Output } \\
\hline 1. Strawberry $(\mathrm{kg})$ & 9305.4 & 17680.3 & - \\
\hline Total energy output (MJ) & - & 17680.3 & - \\
\hline Energy ratio & - & - & 0.48 \\
\hline Energy productivity $\left(\mathrm{kg} \cdot \mathrm{MJ}^{-1}\right)$ & - & - & 0.25 \\
\hline Specific energy $\left(\mathrm{MJ} \cdot \mathrm{kg}^{-1}\right)$ & - & - & 3.96 \\
\hline Net energy $\left(\mathrm{MJ} \cdot \mathrm{ha}^{-1}\right)$ & - & -19142.6 & \\
\hline Direct energy $^{\mathrm{a}}\left(\mathrm{MJ} \mathrm{ha}^{-1}\right)$ & - & 15990.1 & 43.40 \\
\hline Indirect energy $^{\mathrm{b}}\left(\mathrm{MJ} \mathrm{ha}^{-1}\right)$ & - & 20832.8 & 56.60 \\
\hline Renewable energy ${ }^{\mathrm{c}}\left(\mathrm{MJ} \mathrm{h}^{-1}\right)$ & - & 9390.6 & 25.50 \\
\hline Non-renewable energy ${ }^{\mathrm{d}}\left(\mathrm{MJ} \cdot \mathrm{ha}^{-1}\right)$ & - & 27432.3 & 74.50 \\
\hline
\end{tabular}

Table 3: Economic analysis of strawberry production

\begin{tabular}{lr}
\hline Cost and return items & \multicolumn{1}{c}{ Value } \\
\hline Total production costs $\left(\$ . \mathrm{ha}^{-1}\right)$ & 9493.30 \\
Gross production value ${ }^{\mathrm{a}}\left(\$ . \mathrm{ha}^{-1}\right)$ & 14110.20 \\
Benefit $/$ cost ratio & 1.49 \\
Productivity $\left(\mathrm{kg} . \$^{-1}\right)^{\mathrm{b}}$ & 0.98 \\
Net return $\left(\$ \mathrm{ha}^{-1}\right)$ & 4616.90 \\
\hline
\end{tabular}

${ }^{\mathrm{a}}$ : Gross production value $=$ strawberry yield $\left(\mathrm{kg} \cdot \mathrm{ha}^{-1}\right)^{*}$ price $\left(\$ \cdot \mathrm{kg}^{-1}\right)$;

b: Productivity $\left(\mathrm{kg} \cdot \$^{-1}\right)=$ strawberry yield $\left(\mathrm{kg} \cdot \mathrm{ha}^{-1}\right) /$ total production costs $\left(\$ \cdot h a^{-1}\right)$

This result is marvelous, because diesel fuel is one of the most energy consumers in the major of the studies, while in this study the case is inversed. That's because of that the major of the agricultural operations was done manually and using the agricultural machinery was limited to some areas and only for land preparation.

Energy efficiency (energy output-input ratio) in this study was 0.48 and energy productivity calculated as $0.25 \mathrm{~kg} \cdot \mathrm{MJ}^{-1}$ in the study area. This means that $0.25 \mathrm{~kg}$ of output obtained per unit energy. Specific

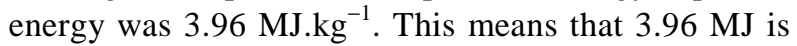
needed to obtain $1 \mathrm{~kg}$ of strawberry. Net energy was19142.6 MJ.ha ${ }^{-1}$. As it's obvious, the net energy in the study area was negative. This means that the amount of output energy is less than input energy and production in this situation is irrational.

Direct, indirect, renewable and non-renewable forms of input energy are also shown in Table 2. The share of $56.6 \%$ of the total energy input was depended on the indirect form, whereas $43.4 \%$ of the total energy input was in the direct form. The share of renewable energy was $25.5 \%$ in the total energy compared to $74.5 \%$ for the non-renewable energy. Therefore, it revealed that the rate of indirect energy was greater than that of direct energy consumption in strawberry production. This result was in agreement with the results of Ozkan et al. (2004) for lemon and mandarin and Esengun et al. (2007b) for apricot. The rate of non-renewable energy also was higher than that of renewable energy consumption in surveyed farms; similar results have been found by Kizilaslan (2009) and Esengun et al. (2007a) for cherries and stake-tomato.

Economic analysis of strawberry production: The data obtained from economic analysis are presented in Table 3 . The benefit/cost ratio was 1.49 in the study area. The productivity was $0.98 \mathrm{~kg}$. $\$^{-1}$ for the strawberry production. Net profit was $4616.9 \$ . \mathrm{ha}^{-1}$. Apparently this shows that producing strawberry is profitable in the study area, but the real net return could be less than this amount by eliminating the subsidies. In many developing countries like Iran, the governments pay subsidies for energy resources or inputs for the production, thus the appropriate yield, efficiency and profitability could not be attained. By eliminating the subsidies, the resources would be used in an efficient manner.

\section{CONCLUSION}

In this study the energy indices and cost analysis of strawberry production in Kamyaran zone of Iran 
have been investigated. Total energy used in various farm operations during strawberry production was 36822.9 MJ.ha ${ }^{-1}$. Energy productivity estimated as $0.25 \mathrm{~kg} \cdot \mathrm{MJ}^{-1}$ and energy efficiency was 0.48 . Specific energy calculated as $3.96 \mathrm{MJ} . \mathrm{kg}^{-1}$. The profit-cost ratio, productivity and net profit in the strawberry production were $1.49,0.98$ and $4616.9 \$ . \mathrm{ha}^{-1}$, respectively.

\section{REFERENCES}

Biswas, M.K., M. Hossain and R. Islam, 2007. Virus free plantlets production of strawberry through meristem culture. World J. Agric. Sci., 3: 757-763. http://www.idosi.org/wjas/wjas3\%286\%29/9.pdf

Demircan, V., K. Ekinci, H.M. Keener, D. Akbolat and C. Ekinci, 2006. Energy and economic analysis of sweet cherry production in Turkey: A case study from Isparta province. Energy Convers. Manage., 47: 1761-9. DOI: 10.1016/j.enconman.2005.10.003

Erdal, G., K. Esengun, H. Erdal and O. Gunduz, 2007. Energy use and economical analysis of sugar beet production in Tokat province of Turkey. Energy, 32: 35-41. DOI: 10.1016/j.energy.2006.01.007

Esengun, K., G. Erdal, O. Gunduz and H. Erdal, 2007a. An economic analysis and energy use in staketomato production in Tokat province of Turkey. Renewable Energy, 32: 1873-81. DOI: 10.1016/j.renene.2006.07.005

Esengun, K., O. Gunduz and G. Erdal, 2007b. Inputoutput energy analysis in dry apricot production of Turkey. Energy Convers. Manage., 48: 592-8. ISSN: 0196-8904.

DOI: 10.1016/j.enconman.2006.06.006

Fluck, R.C. and C.D. Baird, 1982. Agricultural energetic, In: Westport. AVI Publications, CT, pp: 41-126.

Kikas, A. and A. Luik, 2002. The influence of different mulches on strawberry yield and beneficial entomofauna. Proceeding of the 4th International Strawberry Symposium, (ISS'02), ISHS, Leuven, Belgium, pp: 701-704. http://polli.emu.ee/failid/publikatsioonid/different_ mulches.pdf
Kirkpatrick, D., 2008. Growing strawberries. http://9am.ten.com.au/30._Strawberries_31.10.08.p df.

Kitani, O., 1999. Energy and Biomass Engineering. In: CIGR Handbook of Agricultural Engineering, Vol. V, ASAE Publication, St. Joseph, MI., pp: 330.

Kizilaslan, H., 2009. Input-output energy analysis of cherries production in Tokat province of Turkey. Applied Energy, 86: 1354-1358. DOI: 10.1016/j.apenergy.2008.07.009

Mandal, K.G., K.P. Saha, P.K. Ghosh, K.M. Hati and K.K. Bandyopadhyay, 2002. Bioenergy and economic analysis of soybean-based crop production systems in Central India. Biomass Bioenergy, 23: 337-345. DOI: 10.1016/S09619534(02)00058-2

Mohammadi, A. and M. Omid, 2010. Economical analysis and relation between energy inputs and yield of greenhouse cucumber production in Iran. Applied Energy, 87: 191-196. DOI: 10.1016/j.apenergy.2009.07.021

Ozkan, B., H. Akcaoz and F. Karadeniz, 2004. Energy requirement and economic analysis of citrus production in Turkey. Energy Convers. Manage., 45: 1821-30. DOI: 10.1016/j.enconman.2003.10.002

Salami, P., A. Keyhani and S. Rafiee, 2009. The impact of farm size on energy use and profitability of red bean production in Iran: A case study in Kurdistan province. Nature Sci., 7: 95-104. www.sciencepub.net/nature/0709/ns0709.pdf.

Salami, P., H. Ahmadi and A. Keyhani, 2010. Estimating the equivalent energy for single super phosphate production in Iran. J. Sci. Rev., 2: 1-10. http://srbmag.org/index.php/srbmag/article/viewAr ticle/24

Singh, M.K., S.K. Pal, R. Thakurand U.N. Verma, 1997. Energy input-output relationship of cropping systems. Indian J. Agric. Sci., 67: 262-266.

Singh, S. and J.P. Mittal, 1992. Energy in Production Agriculture. 1st Edn., Mittal Pub, New Delhi, ISBN: 8170994071, pp: 166. 